\title{
Refugees and the Problems in Indonesia
}

\author{
Puji Sulistyaningsih ${ }^{1}$, Yulia Kurniaty ${ }^{2}$, Suharso $^{3}$, Cahya Yoga Aditama ${ }^{4}$ \\ \{yuliakurniaty@ummgl.ac.id ${ }^{2}$ \} \\ Faculty of Law, University of Muhammadiyah Magelang, Indonesia ${ }^{1,2,3,4}$
}

\begin{abstract}
The existence of refugees in Indonesia requires serious attention. Social conflict can arise due to psychological pressures as people who are not allowed to work when they need the cost of living, should not go to formal school even though the provision of science is expected changing the future, health services are only obtained from NGOs partners UNHCR, also prohibited owning property. This is done by the Indonesian government in order to protect and prioritize the rights of its citizens over foreign nationals. However, as a country that signed The Declaration on Human Rights (although it did not ratify the 1951 Convention and the 1967 Protocol on the Status of Refugees), Indonesia has a moral obligation to help fellow human beings by providing temporary shelter and life support which is certainly not permanent and far from sufficient. The active role from the Security Council of United Nations to immediately realize peace in war conflict areas is the main solution, rather than simply waiting for third countries to raise quotas to accept refugees.
\end{abstract}

Keywords: Indonesia's refugee problem, world peace

\section{Introduction}

Basically, every refugee or asylum seeker to another country has the right of safety and security protection. In this study, the authors limit the object of study to refugees, not including internally displaced persons and asylum seekers. The difference in the meaning of the three terms is explained by Iin Karita Sakharina and Kadarudin [1], refugees is a group of people who leave their country (crossing national borders); forced because of their fear of persecution, torture or threats of torture, expulsion, political resistance. or rebels on the grounds of race, religion, nationality and other membership with certain social groups. Internally Displaced Person (IDPs) are people or groups of people who have been forced to flee or leave their homes or places where they used to live primarily as a result of or in order to avoid the effects of armed conflict, vulnerable situations characterized by widespread acts of violence in general, human rights violations and those that do not cross internationally recognized national borders [27]. Asylum seekers are people who request protection and submit an application to UNHCR to be declared a refugee after going through a refugee status determination procedure.

Like Indonesia, as a transit country that implements such protection as a form of implementation of the 1945 Constitution of the Republic of Indonesia, Article 28G paragraph (2) which reads: "Everyone has the right to be free from torture or other degrading treatment and has the right to obtain asylum. politics from other countries". Its implementation as a country that ratifies the The Declaration on Human Rights is stated in Article 28 of the Human Rights Law No.39 of 1999 which states that "Everyone has the right to seek asylum to obtain political protection from other countries." This humanitarian mission was carried out because 
the war conflict in the country of origin became the main factor for them fleeing from seeking safety and a new life in another country [2].

However, efforts to improve their lives and future are not as beautiful as hopes, being stranded in a transit country like Indonesia for years as they wait for UNHCR to determine their status, making the refugees very dependent on assistance [3]. As foreigners living in Indonesia without official documents, they have no right to work, have a place to live and get formal education services [4], poor health services even though they should receive more attention during the Covid-19 pandemic [5] make refugees despair [6] and even some who experience psychological disorders [7].

For this reason, the Indonesian government needs to make progressive efforts on refugee handling policies, not limited to the implementation of Presidential Regulation No. 125 of 2016, it is very necessary to emphasize a statement of attitude on the 1951 Convention and 1967 Protocol concerning the handling of refugees, increase cooperation with UNHCR and IOM to realize good benefits for Indonesian citizens and refugees [8]. There are concerns about social problems due to conflicts of interest between local residents (indigenous people) who want a safe and comfortable living environment with refugees who want to survive in the hope of being sent to a third country [9] [10]. The uncertain period of waiting and events experienced during the evacuation journey often causes trauma [11] and various health problems while living in the refugee shelter [12]. As a manifestation of Indonesia's role in actively participating in realizing world peace, it is to encourage the UN Security Council to be more empowered in resolving disputes between countries without using violence, let alone war [13].

\section{Method}

Data collected from literature study on the legal basis for foreign refugees, articles and online news covering refugee problems in realizing their aspirations to live in a country without war conflicts. The data that has been collected is then analyzed descriptively qualitatively by matching its legal basis with the realities of handling refugee problems at the national and global levels using deductive thinking logic, so that solutions can be constructed for how best the government's efforts should be in dealing with refugee problems.

\section{Results and Discussion}

\subsection{The problems that arise with the existence of foreign refugees for Indonesia}

The entry of foreign citizens into Indonesia without official documents certainly raises concerns that it will have an impact on state security, such as bringing and spreading atheism or vice versa, circulating narcotics as an effort to exterminate Indonesia's young generation. Therefore, the Circular of the Director General of Immigration No. IMI-1489.UM.08.05 of 2010 is a shield to protect territorial security from the activities of immigrants who enter Indonesian territory, that they will not be deported as long as they have a refugee certificate issued by UNHCR, are released from the Immigration Detention Center (Rudenim) and their needs will be supported by IOM or UNHCR during the waiting period. As for those whose applications are rejected (as refugees) by UNHCR, they will be detained at the detention center, subject to fines, and/or deported [4]. 
The lack of awareness of the refugees to maintain the cleanliness of the environment in the location where they live temporarily causes garbage piles that spreads an unpleasant aroma. They set up tents on the sidewalk to live in because the building where they were accommodated (Rumah Detensi Imigrasi/other regional government asset building) no longer fits. This condition has been complained by local residents because the environment has become slum and unhealthy, so they are feared to be a source of disease.

As a country with a population of 268.5 million [14], 26.42 million people or $9.78 \%$ with the poor status [15], it is only right that the Indonesian government prioritizes the available funds for poverty alleviation for its citizens, so that not to sign conventions and protocols for handling refugees is a necessity. The limitation of Funding Assistance from The Government of Indonesia is a logical reason for not allocating special funds to support foreign refugees because Indonesia's status as a transit country so there is no obligation.

For humanitarian reasons, The Government of Indonesia provides temporary housing, namely by transferring the function of Rudenim, which should function as a temporary detention center for foreigners who violate immigration regulations in Indonesia. In terms of health and education, NGOs are partners of UNHCR in Indonesia [16].

\subsection{Foreign refugees handling by indonesia government}

\subsubsection{Strategic efforts}

An invention against refugees tossed around the sea or stranded on the mainland territory of Indonesia will be carried out relief efforts by accommodating them in a place that has been provided by the government as a temporary shelter(shelter). In this shelter they will get food, treatment and data collection by UNHCR and accompanying NGOs. In today, UNHCR cooperates with IOM (International Organization for Migration), Dompet Dhuafa, CRS (Catholic Relief Services), CWS (Church World Service), PMI (Indonesian Red Cross), Tzu Chi Foundation, e.g. refugees from Vietnam [17] and Rohingnya [18].

The government conducts patrols around the shelters to ensure it can create a sense of security for the environment around the refugee shelters. This security is a form of anticipation so that there is no social friction between refugees and indigenous peoples, which could arise due to cultural differences and the need for living [19].

Immigration Control by continuously updating the data on the identity and documents of refugees, taking photos and fingerprints. Ensuring refugees are required to report every month to the head of the Immigration Detention House. This is necessary to ensure that no refugee commits acts against the law [20]. The mode of marrying natives needs to be watched out for as a refugee's effort to obtain Indonesian citizen status and stay permanently in Indonesia [21].

\subsubsection{Diplomacy efforts}

The efforts made by UNHCR have been voluntary return to the country of origin or departure to a third country. These two choices are difficult things to realize. Waiting for the country of origin of the refugees to reach a peaceful situation so that it deserves to be a place of life is like waiting for peace between Israel and Palestine [22]. Likewise, waiting for departure to a third country is like waiting for rain to fall in the Sahara [23]. Therefore, Indonesia together with countries in the ASEAN region must not tire of calling for peace efforts through the UN Security Council [24]. The war conflict which resulted in the absence of peace in their homeland was the main factor triggering the wave of refugees and asylum seekers. The UN Security 
Council has the power to resolve disputes in international law that do not require the prior consent of the parties [25].

Likewise, Indonesia needs to affirm to UNHCR that it will continue to help refugees who are stranded (or deliberately stranded or stranded by irresponsible people) in Indonesian territory but that does not mean that they must be able to support them. If third countries only reduce the quota for refugee arrivals for financial and security reasons [26], it would be unfair for the Indonesian government to bear the consequences.

\section{Conclusion}

Being a refugee is certainly not the main life choice, but the peace situation in a country makes them flee for a new life in another country where no war conflict. Therefore, the Security Council of United Nations should be more active in creating world peace in order to reduce the number of refugees due to war conflicts. Encourage UNHCR to conduct diplomacy with the third country so as not to reduce the quota in accepting refugees according to the original commitment. Refugees are allowed to work in a limited scope to meet the cost of living and under close supervision while awaiting status determination by UNHCR.

\section{References}

[1] I. K. Sakharina and Kadarudin, Pengantar Hukum Pengungsi Internasional (Perbedaan Istilah Pencari Suaka, Pengungsi Internasional dan Pengungsi Dalam Negeri). Yogyakarta: Deepublish (CV Budi Utama), 2017.

[2] Muhammad Radityo Priyasmoro, "Nasib Pengungsi: Terlunta-lunta di Indonesia, Ditolak Negeri Impian,” Liputan6.com, 02-Aug-2019.

[3] "Demonstrasi di Jakarta, pengungsi Afghanistan meminta dikirim ke negara ketiga," BBC News Indonesia, 06-Feb-2017.

[4] SUAKA Secretariat, "Refugees and Asylum Seekers in Indonesia," SUAKA : Indonesian Civil Society Association For Refugees Rights Protection, 2020. [Online]. Available: https://suaka.or.id/public-awareness/refugees-and-asylum-seekers-in-indonesia/.

[5] Iin Karita Sakharina, "Perlindungan Negara Bagi Pengungsi Pada Masa Pandemi Global COVID19: Kajian Hukum Internasional,” Al-Azhar Islam. Law Rev., vol. 2, no. 2, 2020.

[6] BBC News Indonesia, "Kisah pengungsi di Indonesia: 'Kami ingin bertahan hidup, itulah kenapa kami di Indonesia,"” 2020, Jun-.

[7] Yuriy Nesterko, D. Jäckl, M. Friedrich, L. Holzapfel, and H. Glaesmer, "Factors predicting symptoms of somatization, depression, anxiety, post-traumatic stress disorder, self-rated mental and physical health among recently arrived refugees in Germany," Confl. Health, 2020.

[8] Wahyu Satrio Wiguna, "Kebijakan Penanganan Pengungsi Asing di Indonesia," Universitas Islam Negeri Sunan Kalijaga Yogyakarta, 2018.

[9] M. Sundvall, D. Titelman, V. DeMarinis, L. Borisova, and Ö. Çetrez, "Safe but isolated - an interview study with Iraqi refugees in Sweden about social networks, social support, and mental health," Int. J. Soc. Psychiatry, 2020.

[10] Seraina Ru"egger, "Refugees, ethnic power relations, and civil conflict in the country of asylum," J. Peace Res., vol. 56, no. 1, 2019.

[11] J. Ben Farhat et al., "Syrian refugees in Greece: experience with violence, mental health status, and access to information during the journey and while in Greece," BMC Med., 2018. 
[12] Y. Duzkoylu, S. I. Basceken, and E. C. Kesilmez, "Physical Trauma among Refugees: Comparison between Refugees and Local Population Who Were Admitted to Emergency DepartmentExperience of a State Hospital in Syrian Border District," Hindawi J. Environ. Public Heal., 2017.

[13] Jawahir Thontowi, Hukum Internasional Kontemporer. Bandung: PT. Refika Aditama, 2006.

[14] Dian Erika Nugraheny, "Data Kependudukan 2020: Penduduk Indonesia 268.583.016 jiwa," Kompas.com, 2020.

[15] Dwi Hadya Jayani, "Tingkat Kemiskinan Terbesar Indonesia Ada di Wilayah Ini," databoks.katadata.co.id, $2020 . \quad$ [Online]. Available: https://databoks.katadata.co.id/datapublish/2020/07/16/tingkat-kemiskinan-terbesar-indonesia-adadi-wilayah-ini.

[16] U. Indonesia, "Kerjasama dan Perlindungan Berbasis Komunitas," 2020. [Online]. Available: https://www.unhcr.org/id/kerjasama-dan-perlindungan-berbasis-komunitas.

[17] Rosmawati, "Perlindungan Terhadap Pengungsi/Pencari Suaka Di Indonesia (Sebagai Negara Transit) Menurut Konvensi 1951 Dan Protokol 1967,” Kanun J. Ilmu Huk., vol. 67, no. XVII, 2015.

[18] H. A. S.D and M. K. Juani, "Kebijakan Pemerintah Indonesia melalui Sekuritisasi Migrasi Pengungsi Rohingya di Aceh tahun 2012-2015," Indones. Perspect., vol. 2, no. 1, 2017.

[19] Fajar Setyadi, "Pencari Suaka Masih dalam Problema," validnews, 2019.

[20] Muhammad Alvi Syahrin, "Menakar Kedaulatan Negara dalam Perspektif Keimigrasian," J. Penelit. Huk. Jure, vol. 18, no. 1, 2018.

[21] M. Alvi Syahrin and H. B. Artono, "Legal Impacts of The Existence of Refugees and Asylum Seekers In Indonesia,” Int. J. Civ. Eng. Technol., vol. 9, no. 5, 2018.

[22] PTRI New York/Kemlu RI, "Indonesia Terpilih Kembali Menjadi Wakil Ketua Komite Palestina PBB,” Kementrian Luar Negeri RI, 2020. [Online]. Available: https://kemlu.go.id/portal/id/read/1019/view/indonesia-terpilih-kembali-menjadi-wakil-ketuakomite-palestina-pbb.

[23] A. Sumandoyo, "Kebijakan Trump soal Pengungsi Membahayakan Indonesia," tirto.id, 2017.

[24] "Sidang Dewan Keamanan PBB Dimulai, Indonesia Bahas Konflik Yaman, Suriah, Mali, dan Somalia," Waspada Online, 2020.

[25] Sefriani, Hukum Internasional Suatu Pengantar. Jakarta: Rajawali Pers, 2016.

[26] Prasetyo Utomo, “Kemlu: Masalah Pengungsi Afghanistan di Jakarta Kewenangan UNHCR," Media Indonesia, 2019.

[27] Noviasari, D. T., \& Nurwati, N. (2020). Perlindungan Tenaga Kerja Disabilitas dalam Perspektif Hak Asasi Manusia. Borobudur Law Review, 2(1), 16-29. 